\title{
Parasitosis of the Chukar Partridge, Alectoris chukar in North Iraq
}

\section{Kuzey Irak’ın Kınalı Keklik (Alectoris chukar) Parazitleri}

\author{
Shlemon Al-Barwari ${ }^{1}$, Isam Saeed ${ }^{2}$ \\ ${ }^{1}$ Formerly of Salahaddin University, Biology Division, Erbil, Iraq \\ 2University Collage of Sjælland, Bioanalytiker, Næstved, Denmark
}

\begin{abstract}
Objective: The aim of this study was to establish the identity of the parasitic communities of the chukar partridge from Iraq as well as reporting on the prevalence and intensity of various infections from several localities and comprising both sexes.

Methods: Twenty-nine live adult chukar partridge (Alectoris chukar) were obtained from several localities across the northern provinces of Iraq. Blood samples were examined for haemoprotozoa, carcasses were assessed for the ectoparasites throughout the body skins and feathers, and the alimentary canal was examined for protozoans and helminths.

Results: All of the examined animals were infected with the 18 different endo- and ectoparasite species identified. These include 2 protozoans, 3 cestodes, 2 nematodes, and 11 arthropods. The overall figures suggest no significant differences in infection indices in terms of the host's sexuality. Pathogenicity of the parasites involved is briefly emphasised. Furthermore, the role of the chukar in the dissemination of these disease agents among populations of other avian species is discussed.

Conclusion: With the exception of $C$. latiproglottina, all of the species differentiated represent new records for chukar from Iraq, and the 2 coccidians are new addenda to the country parasitological list. (Turkiye Parazitol Derg 2012; 36: 240-6)

Key Words: Chukar partridge, parasite, endoparasite, ectoparasite, Irak

Received: 10.04.2012

Accepted: 02.08.2012

\section{ÖZET}

Amaç: Irak'tan toplanan kınalı kekliklerde bulunan parazitlerin yaygınlığı ve yoğunluğunu belirlemek amacıyla yapılmıştır.

Yöntemler: Irak'ın kuzey eyaletlerinden 29 yetişkin kınalı keklik (Alectoris chukar) canlı olarak toplanmış, deri ve tüyler ektoparazit, sindirim kanalı protozoon ve helmintler, kan ise Haemoprotozoa yönünden incelenmiştir.

Bulgular: Incelenen örneklerin tümü parazitlerle enfekte bulunmuş ve hayvanlardan 2 protozoan, 3 sestod, 2 nematod ve 11 artropod olmak üzere toplam 18 farklı tür parazit saptanmıştır. Sonuçlar, konak cinsiyetine göre enfeksiyon sıklığında önemli bir farklılık olmadığını göstermiştir. Parazitlerin patojenitesi de kısaca incelenmiş, bu hastalık ajanlarının diğer kuş türleri arasındaki dağılımında kınalı kekliklerin oynadığı rol de tartışımıştır. Sonuç: Cotugnia latiproglottina dışında diğer türlerin tamamı Irakta kınalı keklikte ilk kez bildirilmekte, Eimeria kofoidi ve E. caucasica ise Irak için ilk kayıttır. (Turkiye Parazitol Derg 2012; 36: 240-6)
\end{abstract}

Anahtar Sözcükler: Kınalı keklik, parazit, endoparazit, ektoparazit, Irak

Kabul Tarihi: 02.08.2012

\section{INTRODUCTION}

The chukar partridge (Alectoris chukar) is a common Eurasian species. It is the most important native game bird of the northern region of Iraq (1). Two of the 14 suggested subspecies are seen in the wild in this country, namely, $A$. c. kurdestanica and A. c. werae $(2,3)$. They are undoubtedly very similar to each other in size and other morphometric traits, general appearance and habits, to the extent that

Address for Correspondence / Yazışma Adresi: Dr. Isam Saeed, University Collage of Sjælland, Bioanalytiker, Næstved, Denmark Phone: 28936531 E-mail: parasitology@live.dk doi:10.5152/tpd.2012.57 
cross-breeding may occur between them. However, it is generally believed that the populations of these subspecies have little overlap in their geographical distributions; for example, the range of kurdestanica is much wider extending from Armenia across southeast Turkey and north Iraq to Iran, while that of werae is merely confined to certain habitats in northeast Iraq and west Iran.

The chukar partridge is known to be capable of producing hybrids with some other members of the genus Alectoris $(2,4)$. Indeed, its hybrids are often more tamed and therefore much easier to be bred and raised on a large-scale. Several nations of the Mediterranean and Middle East regions have taken the male of Alectoris partridge as a symbol of bravery, intelligence and wickedness, and its female as a symbol of passion and motherliness.

Parasitological studies have been conducted on a number of Alectoris species and subspecies in several parts of the world. A wide variety of endo- and ectoparasite species were recovered and identified from them. The first category is mainly composed of gastrointestinal protozoans and helminths, with average infection figures roughly clustering around $50 \%$. Relevant data were made available upon many investigations, such as those of Ruff and Wilkins (5) on A. chukar from the USA; Vasilev (6) on A. chukar kleini from Bulgaria; Reck and McQuistion (7), Koroglu and Tasan $(8,9)$ and Perrucci et al. (10) on A. graeca from the USA, Turkey and Italy, respectively; Belleau and Leonard (11) and Rizzoli et al. (12) on A. graeca saxatilis from France and Italy, respectively; Moretti et al. (13) and Carvalho-Varela and Ferradeira (14) on A. rufa from Italy, Spain and Portugal, respectively, and Calvete et al. (15) also on A. rufa from Spain. With respect to the ectoparasites, less systematic research seems to have been done $(14,16,17)$, but nevertheless reveals infestation of these birds by many species, most commonly lice, fleas and ticks.

On the other hand, the situation in Iraq, as in other Middle East countries, still lags behind. That is to say, the knowledge on Alectoris partridges is mostly narrative and zoogeographical. Indeed, the literature survey shows that these birds were examined with a parasitological intention on only two occasions. Arthur (18) described a few specimens carrying a new species of ixodid ticks (Ixodes tatei), while Sawada et al. (19) found a single specimen of a new species of davaneid tapeworms. Upon the description of the latter, the name Cotugnia latiproglottina was assigned to it (typewritten in the original abstract as $C$. paucitesticulata by mistake).

The present study, therefore, aims to establish the identity of the parasitic communities of the chukar partridge from Iraq as well as reporting on the prevalence and intensity of various infections. The sample size employed was much larger than the preliminary ones referred to above, as well as being more representative by virtue of obtaining it from several localities and comprising both sexes.

\section{METHODS}

The study depended on examining 29 (11 male and 18 female) chukar partridge, Alectoris chukar (Gray, 1830) (Galliformes, Phasianidae). All of the specimens were adult and older than one year, as judged from the observation of the plumage pattern and weight. Sex differentiation was always confirmed by gonadal checking. The birds were obtained alive from hunters or dealers on different occasions from several localities across the northern provinces of Iraq. The vast majority of them were recognised as A. c. kurdestanica Meinertzhagen, 1923, and only a couple (probably 3) as A. c. werae (Zarudny and Loudon, 1904). Accordingly, no attempt was made to discriminate the parasitological data on the basis of the host subspecies.

Each bird was given a thorough examination with the results showing that almost all of them were vigorously active. None of them showed injuries, marked skin lesions (such as hyperdermatosis, epidermitis and acanthosis) or excessive feather loss or damage. However, some of them discharged moistened faeces and a pair had severe diarrhoea. The latter exhibited poor feeding and drinking and their bodies were markedly dehydrated.

The respective average figures of 6 morphometric parameters that were determined for 10 male and 10 female chukar specimens were as follows: body length (bill to tail) 36.4 and $31.7 \mathrm{~cm}$, body mass 703.8 and $448.5 \mathrm{~g}$, wing cord 47.9 and $45.9 \mathrm{~cm}$, tail length 83.3 and $80.5 \mathrm{~cm}$, tarsus length 47.5 and $43.9 \mathrm{~cm}$, and bill length 15.0 and $14.4 \mathrm{~cm}$.

Blood samples were employed following a procedure specified by Al-Barwari and Saeed (20). From each partridge, a small amount of blood was drawn from the wing vein. This was prepared into thin smears that were air-dried, fixed in absolute methyl alcohol and stained following the Giemsa method (5\%, $\mathrm{pH}$ 7.2). The slides were microscopically examined for the presence or absence of haemoprotozoa.

Partridge carcasses were assessed for the ectoparasites throughout their body skins and feathers. Wherever found, these organisms were mostly removed by fingers and sometimes by small forceps. Preservation, clearance, staining and species differentiation of these parasites were also performed as described previously (20). The same was applied to the determination of the prevalence rates and intensities of infection for each species and for both sexes of the host.

Evisceration of each bird was then performed and the alimentary canal was opened by a longitudinal incision. Fresh samples of the contents of and scrapings from the mucous membranes of each part (mouth, oesophagus, crop, stomach, gizzard, small intestine, rectum and caeca) were transferred to glass slides, mixed with drops of saline, covered with coverslips and examined microscopically for protozoans, helminth segments and ova. Livers and gallbladders were examined for trematodes, and tracheas for nematodes. Upon finding the adult helminths, they were collected separately from each bird, cleared in saline, counted, identified as far as possible, fixed in $70 \%$ ethanol, and then stored in $70 \%$ ethanol $+5 \%$ glycerine for subsequent use.

Standard procedures were frequently employed for the purpose of permanent preparations of any gastrointestinal protozoan, cestode and nematode parasites that were present. Definite identification to the species level was achieved by studying the characteristic features of the parasite forms. A floatation technique was often employed to confirm the identification of Eimeria species; it was also used to arbitrarily determine the 
infection density for these parasites, for example, by designating $1+$ for asymptomatic infection and where relatively only small numbers of oocysts were detectable; $2+$ for moderate infection and symptoms, such as slight diarrhoea; and 3+ for acute symptoms, including severe diarrhoea, emaciation and in appetence.

\section{RESULTS}

The total number of parasite species encountered in and on the chukars was 18 . Thirteen (44.8\%) of the specimens examined were found to harbour at least one helminthic species. However, when combined with the results on ectoparasites, all of the host specimens were found to be parasitised with one or more species. Indeed, about $50 \%$ of the partridges harboured 7 or more species of parasites simultaneously.

Table 1 Lists the scientific names of the parasites that were found together with their infection sites in or on both sexes of the host, as well as the respective infection rates and parasite burdens. Internal infections were only encountered in the small intestine and caeca. The upper digestive tracts of all of the sampled chukars were found to be negative for the infection by the flagellate protozoan Trichomonas gallinae, and no haemoprotozoans, like Haemoproteus and Plasmodium, were detected in blood smears or trematode species in livers or gallbladders. The mouth, oesophagus and crop of all of the sampled chukars revealed no infection with Capillaria nematodes. Also, the tracheas of all specimens were found to be free of infection by helminths like the gapeworm Syngamus trachea. However, two species of intestinal protozoans, three species of intestinal tapeworms, one species of intestinal and another of caecal nematodes, and 11 species of ectoparasites were identified.

The two eimeriid protozoans recovered were identified as Eimeria kofoidi Yakimoff and Malikaschwili, 1936 and E. caucasica Yakimoff and Buewisch, 1932. The host site preference for either of the above species is the small intestine. Their prevalence was moderately higher in female than male hosts. The index of parasite burden, although only arbitrarily measured for infection by these species, tends to suggest the existence of an association between the intensity of infection and severity of symptoms in the diseased specimens.

The three forms of tapeworms differentiated were all found to be davaineid species, namely Raillietina (Raillietina) tetragona (Molin, 1858), Cotugnia latiproglottina Sawada et al. (19) 1990 and Choanotaenia infundibulum (Bloch, 1779). The vast majority of the specimens were bound through their scolices to the mucosa of small intestine, but some were present free in the lumen of this organ. Male chukars seemed to be more prone to parasitisation by anyone of these tapeworms than the female counterparts, but it is unclear whether that is in terms of prevalence or intensity.

One of the two nematode species that were identified, namely Heterakis gallinarum (Schrank, 1788) was encountered in the

Table 1. Parasites harboured by the chukar partridge from north Iraq together with the infection indices in male and female sample

\begin{tabular}{|c|c|c|c|c|c|}
\hline \multirow[t]{2}{*}{ Parasite name } & \multirow[t]{2}{*}{ Infection site } & \multicolumn{2}{|c|}{ Infection rate (\%)* } & \multicolumn{2}{|c|}{ Parasite burden ${ }^{\star \star}$} \\
\hline & & 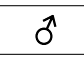 & 우 & 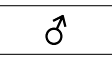 & ㅇ \\
\hline E. kofodi $* \star \star$ & Intestine (oocyctc in faeces) & 36.4 & 50.0 & $1+-2+$ & $1+-3+$ \\
\hline E caucasica ${ }^{\star \star \star}$ & $=\quad=\quad=\quad=$ & 27.3 & 44.4 & $1+-3+$ & $1+-3+$ \\
\hline R. (R.) tetragona & Small intestine & 27.3 & 16.7 & 2.3 & 2.7 \\
\hline C. latiproglottina & $=\quad=$ & 18.2 & 11.1 & 6.0 & 3.0 \\
\hline C. infundibulum & $=$ & 9.1 & 0 & 2.0 & 0 \\
\hline H. gallinarum & Intestinal caecum & 18.2 & 27.8 & 4.0 & 2.4 \\
\hline A. galli & Small intestine & 9.1 & 16.7 & 1.7 & 1.3 \\
\hline M. cornutus & Body skin & 45.5 & 38.9 & 54.2 & 27.6 \\
\hline C. columbea & Wing feather and skin & 9.1 & 22.2 & 2.0 & 3.8 \\
\hline G. dispar & Feather and skin & 9.1 & 5.6 & 7.0 & 28.0 \\
\hline C. heterographus & Head and neck & 0 & 11.1 & 0 & 10.5 \\
\hline L. caponis & Wing feather and skin & 0 & 5.6 & 0 & 7.0 \\
\hline C. lectularis & Body skin & 9.1 & 11.1 & 2.0 & 1.3 \\
\hline C. felis & $=\quad=$ & 18.2 & 0 & 1.5 & 0 \\
\hline D. gallinae & $=$ & 9.1 & 16.7 & 1.7 & 2.3 \\
\hline I. frontalis & $=$ & 9.1 & 5.6 & 2.0 & 1.0 \\
\hline H. asiaticum & $=$ & 0 & 11.1 & 0 & 1.0 \\
\hline A. persicus & $=$ & 27.3 & 16.3 & 3.3 & 2.7 \\
\hline
\end{tabular}


caeca, whereas the second species, Ascaridia galli (Schrank, 1788), was found in the small intestine. The posterior extremity of an adult male of the latter species revealed some minor morphological variations in comparison with the specimens commonly found in Iraqi poultry (chicken, turkey and duck). For both of these nematode parasites, it was the female chukar that showed the higher susceptibility for infection, while the opposite was noted in respect to the index of parasite burden.

The study encountered 11 species of ectoparasites. Seven of them were insects, comprising five Mallophaga, namely, the small body louse Menacanthus cornutus Schrommer, 1913, the feather louse Columbicola columbae (Linnaeus, 1758), the large louse Goniodes dispar Burmeister, 1838, the head louse Cuclotogaster heterographus Nitzsch, 1866, and the wing louse Lipeurus caponis (Linnaeus, 1758); one Heteroptera, the common bed bug Cimex letularius Linnaeus, 1758, and one Siphonaptera, the common cat flea Ctenocephalides felis (Bouche, 1835). The other four species were Arachnida, the first an Acarina, the poultry red mite Dermanyssus gallinae (De Geer, 1778), and the second, third and fourth Acari, the front hardbodied ticks Ixodes frontalis (Panzer, 1798), Asiatic hard-bodied tick Hyalomma asiaticum Schulze and Schlottke, 1929, and Persian poultry soft-bodied tick Argas persicus (Oken, 1818).

Harbouring of chukar to ectoparasite species revealed a wide range of variability in terms of prevalence (approximately $0-46 \%$ in males and $0-39 \%$ in females). The highest sex-combined infestation rate recorded was for $M$. cornutus, followed by $C$. columbae and then $D$. gallinae; whereas the lowest such rate was for $L$. caponis and $H$. asiaticum, where in either of them only a single case of infection was found (Table 1). Differences were also detected with respect to parasite burden (approximately 0-54 in males and 0-28 in females), again with higher average figures for M. cornutus but followed by $G$. dispar; whereas the lowest burden was in $\mathrm{H}$. asiaticum followed by $\mathrm{C}$. felis.

\section{DISCUSSION}

A couple of the chukar specimens suffering from acute diarrhoea were constantly lighter in weight than the rest. They often harboured more parasite species, with coccidians always being present in their intestines. This finding supports a previous one made on the rock pigeon, which indicated that some of the biometric measurements might turn out to serve as an arbitrary indicator of the general health status of the adult bird (20).

Examination of the chukar for endo-parasitosis revealed its infection with cestodes and nematodes besides coccidians, but not with any trichomonal, blood protozoan, trematode or acanthocephalan species. This, in a general sense, is in agreement with what one would expect in the structure of the parasitic communities of this species; partly because of being a seedeater and preferring dry and rocky habitats, and partly in light of the results obtained by several other researchers in comparable ecosystems. However, Millan et al. (21) were able to record for the first time a Haemoproteus sp. in A. rufa from Spain. Also, few digenetic trematodes, such as Brachylaemus fuscatus, Dicrocoelium petrovi and Dicrocoelium sp., have been recovered from adults of other Alectoris partridges $(6,11,12,15,22)$. The absence of
Trichomonas infection in partridges may be explained through the mode of their feeding that does not involve "crop milk", even at a very early age after hatching, without totally eliminating the possibility of some inherited resistance to such infection. The scarcity of blood parasites in these birds is likely to be due to the scarcity of vector agents, but again without eliminating the possibility of some immunological resistance and probably the density of the definitive hosts in that matter. As to the relevance to trematodes, they may well be related to the availability of ill-suited intermediary hosts, which are essential to the survival of their infective stages as well as their free-living stages surviving the outside physical and environmental factors.

The present study showed that at least two species of eimeriid coccidians (E. kofoidi and E. caucasica) are capable of parasitising the Iraqi population of chukar. Besides Russia, which is the country in which they were first discovered, both were also found to be widely distributed among the partridge species in some other countries, for example, $76 \%$ and $38 \%$ of $A$. graeca from Turkey, respectively, and E. kofoidi in $59 \%$ of $A$. graeca in the USA $(7,8,23,24)$. It is worth mentioning here that the total number of Eimeria spp. described from Alectoris partridges may have reached $13(10,25,26)$. However, several of them are widely looked upon as being synonyms of only two or three genuine ones, that is, those which were also recovered in this study and $E$. alectorae $(27,28)$. The latter species was first found in the chukar from India.

The varied pathogenicity produced by coccidian parasites in the sampled partridges was comparable to that observed elsewhere by others $(5,11,13,14)$. That is to say, such infections may or may not be associated with clinical symptoms of acute disease. This suggests that mild infection of these birds by the gastrointestinal coccidians, similar to the situation in poultry and many other species, might be of little effect if not of some advantage to them due to the development of an immunological mechanism $(27,29)$. Several anti-coccidial drugs have been tried in chukar partridges, such as ormetoprim, sulphamethazine, amprolium, dinitolmide, monensin, lasalocid, and sulphonamides. However, it is a medication through feed with sodium sulphamethazine, or a 5:3 mixture of sulphadimethoxine and ormetoprim (Rofenaid), which is apparently much more effective in the treatment and prevention of this type of parasitism in these birds $(5,7)$.

The tapeworm C. latiproglottina was first described by Sawada et al. (19) in chukar from north Iraq. They encountered it as a single mature, non-gravid worm in the small intestine of one out of three kurdestanica specimens obtained from Hareer County, east of Erbil province. The original description of its specific characteristics were found to be justifiable, for example, it is similar to C. transvaalensis Ortlepp, 1963, which was first recorded from the Guinea fowl, but differ from it by having no less than 3-fold longer strobila, a longer vitelline gland and a more massive ovary, with the outline of the latter organ being finally and not coarsely lobated. The present study also extends the epidemiological knowledge pertinent to the infection of chukars by this parasite.

With regard to the two other species of tapeworms found (R. (R.) tetragona and $C$. infundibulum), this is the first record of their 
presence in partridges from Iraq. However, both of them have been reported in these birds from some other places, for example, the former with a prevalence of $6.0 \%$ in $A$. graeca from Turkey (9), and $8.6 \%$ (intensity of 1-5) in A. Rufa from Spain (15); and the latter with a prevalence of $4.0 \%$ in $A$. graeca from Turkey (9), and $8.6 \%$ (intensity of 1-10) in A. rufa from Spain (15).

The fact that the tapeworm species mentioned above are capable of producing diseases in poultry reveals the importance of encountering them in this study (29). Furthermore, they are also capable of infecting several other avian species. In as far as Iraq is concerned, R. (R.) tetragona has been found in 18.5\% (intensity of 4.7 ) of chickens from Mosul (30), $0.2 \%$ of domestic pigeons from north of Iraq, $16.0 \%$ (intensity of 2.2 ) of rock pigeons from various localities, and $16.0 \%$ (intensity of 2.5 ) of the whitecheeked bulbuls from around Baghdad City (20, 30-32). This species was also found to infect the Iraqi populations of the domestic pigeon and wood-pigeon (C. palumbus), which in the latter host exhibited discernible seasonal variations $(33,34)$. As for C. infundibulum, it has been identified in $18.5 \%$ (intensity of 6.7) of chickens from Mosul district (30).

The findings of two species of nematodes $(H$. gallinarum and $A$. galli) represent new records in chukar from Iraq. However, both of them have been identified in some other partridge species from abroad. For example, the prevalence of the former was about $1.0 \%$ of $A$. rufa from the United Kingdom, $12.0 \%$ of $A$. graeca from Turkey, and about $1.2 \%$ (intensity of 1.0 ) of $A . g$. saxatilis from Italy; the latter totalled $5.0 \%$ (intensity range of 2-27) of A. rufa from Spain $(9,12,15,17)$.

The above nematode species have also been found in other avian species from Iraq, for example, $H$. gallinarum in $45.8 \%$ (intensity of 39.4) of chickens from Mosul, and A. galli in $56.4 \%$ (intensity of 29.6) of chickens from Mosul, $0.5 \%$ (intensity of 25) of domestic pigeons from the north of Iraq, and in $6.4 \%$ (intensity of 2.6) of rock pigeon from various localities $(20,30,31)$. As is well documented, the deleterious effect of $H$. gallinarum may stretch beyond its own parasitisation, for this caecal worm is an important vector of the virulent flagellate protozoan Histomonas meleagridis. According to Potts (17) and Calnek (29), histomoniasis (blackhead disease) may be a cause of a considerable number of deaths in the partridge population, as is the case in many other species of gallinaceous birds in the wild where the food comprises insects and other invertebrates, like earthworms.

In agreement with the findings of Rizzoli et al. (12) on the rock partridge from Italy and Al-Barwari and Saeed (20) on the rock pigeon from Iraq, the data of the present study revealed that the association between chukar sex and the overall prevalence rate or infection intensity of any main category of gastrointestinal parasites was not significant.

Parallel to their parasitisation with endoparasites, the infestation of the chukars with ectoparasites was found to be a common phenomenon in north Iraq. A comparable situation was found regarding infestation of the red-legged partridge $A$. rufa in Spain and Portugal $(14,16)$. The latter researchers identified and analysed the data relevant to 13 helminthic (one trematode, four cestodes and eight nematodes) and nine ectoparasite species (six chewing lice and three ticks). Generally speaking, the observations made by them, like those of Al-Barwari and Saeed (20) on the rock pigeon, would suggest that the overall intensity of infestation by lice is primarily controlled by environmental factors. However, the data of the present study as a whole do not collate with that of Calvete et al. (16) regarding a greater association between louse species infestation and male but not female partridges. This is true, whether investigating intensity of infestation or species richness.

The 11 species of ectoparasites identified from the chukar collectively represent a new record for this host from Iraq. However, the lists presented in previous studies in this country, such as those of Al-Barwari and Saeed (20), Al-Hubity (30), Khalaf (35), Abul-Hab (36), and Abdul-Karim et al. (37), would reveal that all of the species have been fairly well recorded. Which of them is also an actual parasite of chukar and which is incidentally encountered due to contamination from other more suitable sources is difficult to say with certainty until further samples are analysed. What can be inferred from observations already made in Iraq is that M. cornutus, G. dispar, C. heterographus, L. caponis, and D. gallinae are commonly found on chickens and other poultry; A. persicus is also prevalent among chickens in north Iraq, with high infection rates and heavy parasite burdens in some localities that are difficult to cope with (38); C. columbae is a specific parasite of pigeons and doves; while the rest of species encountered parasitise a range of mammals, including humans, as well as many birds. The ixodid tick I. tatei was not encountered in this study. This parasite was first described in Iraq by Arthur (18) from the common red fox Vulpes vulpes, as well as from the chukar, upon which it preys. The prevalence rates of ectoparasites and the intensity of their infection reported by the above sources from Iraq varied considerably due to variation of such factors like the host species, seasonality, geographical location within the country and nutritional status. As far as the overall differences in the parasitisation of the two sexes is concerned, the averages of the global data for all species involved in the present study tend to suggest that the individual findings may not be as significant as they appear. In other words, the observed differences are perhaps due to such factors like small sample size, the source, and the ecological circumstances and duration of confinement before examination, more than to the impact of some host-specific intrinsic factors like hormones.

The infection indices for any one of the ectoparasites encountered was generally found to be low and probably not of sufficient severity to be solely responsible for the production of clinical symptoms of illness or alterations in the physiological conditions of the host. However, as discussed by Calnek (29), Calvete et al. (16), and Al-Barwari and Saeed (20), they should be looked upon not only as obligate external parasites but also under certain circumstances where the defence mechanisms are weakened (such as in sick, deformed or senile birds), food deprivation, and heavy and prolonged infection with blood and intestinal parasites, as being capable to populate rapidly and causing serious health deterioration, sexual selection, reduction in fecundity and even mortality of the host by predation or otherwise. What should also be emphasised is the vectorial and reservoir roles of these arthropodan parasites, and the fact that some of 
them act as intermediary hosts to a number of helminthic parasites. Of special interest in this regard was the recovery in this study of 2 specimens of the Asiatic hard tick $H$. asiaticum. This ixodide species is among a number of suspected vectors that may play a role in the transmission of the causative agents of some deadly diseases in Iraq from animals to humans, such as CCHF and RVF viruses $(39,40)$. The researchers were informed that the source of both partridges carrying these ticks was a north-eastern area not too far from the border with Iran.

\section{CONCLUSION}

The researchers recommend carrying out periodic investigations on both endo- and ecto-parasites of the chukar partridge, as well as any other Iraqi wild species wherever possible. This approach will be useful to evaluate the wildlife situation and perhaps also sense the dangers of dissemination of some of the parasitic species to the economically important animals, pets and humans themselves. A policy involving the strict prevention of infection should be employed to prevent the possibility of introduction of an extinct as well as a new species to a particular territory of the country. As emphasised by Tompking et al. (41), parasite-mediated competition between different species need to be defined and dealt with wherever possible. The likelihood of any potential interaction between autochthonous and allopatric species is threatening and should be avoided as much as possible.

\section{Acknowledgments}

The authors are thankful to the officials of the Biology Departments, Colleges of Medicine and Education, Salahaddin University, Erbil, Iraq, for their encouragement and provision of facilities. They also thank the British Library for providing one of them (S.E.B.) with some of the references.

\section{Conflict of Interest}

No conflict of interest was declared by the authors.

\section{REFERENCES}

1. Allouse BA. Birds of Iraq. Vol. 2: Galliforms-Piciforms. Baghdad: Ar-Rabita Press; 1961. (In Arabic)

2. Madge S, McGowan P. Pheasants, Partridges, and Grouse. Princeton, N.J.: Princeton University Press; 2002.

3. W.B.T.L. World Birds Taxonomic List: Genera and Species with Citations 2011; Available from: URL: http://www.zoonomen.net/ avtax/gall.html

4. Christensen CG. Chukar: Alectoris chukar. In: Poole A, Gill F, editors. The Birds of North America. Philadelphia, PA: The Academy of Natural Sciences of Philadelphia 1996.p.1-20.

5. Ruff MD, Wilkins GC. Prevention of coccidiosis in the chukar partridge (Alectoris chukar) by medication with sulfadimethoxine and ormetoprim (Rofenaid R). Poultry Sci 1990; 69: 1675-80. [CrossRef]

6. Vasilev I. Helminth in Thracian rock partridge (Alectoris chukar kleini) in Bulgaria. Helminthologia 1992; 29: 117-23.

7. Reck M, McQuistion TE. The anticoccidial effects of amprolium, monensin and sodium sulfamethazine in farm-reared chukar partridges (Alectoris graeca) in Illinois. T Illinois State Acad Sci 1994; 87: 51-9.

8. Koroglu E, Tasan E. Distribution of Eimeria (Protozoa, Eimeriidae) in quails and partridges in the vicinities of Elazig and Tunceli. Turk $J$ Vet Anim Sci 1995; 19: 187-91.

9. Koroglu E, Tasan E. Distribution of helminths in quails (Coturnix coturnix) and partridges (Alectoris graeca) in the vicinities of Elazig and Tunceli. Turk J Vet Anim Sci 1996; 20: 241-9.
10. Perrucci S, Tarantino C, Cecchi S, Mani P, Macchioni G, Marconcini A. Coccidia isolated from partridge (Perdix perdix) and from rock partridge (Alectoris graeca). Ann Fac Med Vet Pisa 1997; 50: 379-85.

11. Belleau E, Leonard P. Intestinal parasites of rock partridge (Alectoris graeca saxatilis), ptarmigan (Lagopus mutus) and black grouse (Tetrao tetrix) in the Hautes-Apes Department. Gibier, Faune Sauvage 1991; 8: 161-73.

12. Rizzoli A, Manfredi MT, Rosso F, Rosa R, Cattadori I, Hudson P. Intensity of nematode infections in cyclic and non-cyclic rock partridge (Alecdtoris graeca saxatilis) populations. Parassitologia 1999; 41: $561-5$

13. Moretti A, Fioretti DP, Tacconi G, Nobilini N. Prevalence of parasitoses on semi-intensive game bird farms in Umbria. Obiettivi e Documenti Veterinari 1992; 13: 53-5.

14. Carvalho-Varela M, Ferradeira C. Parasites and parasitic diseases in the red partridge (Alectoris rufa) in the Iberian Peninsula. Some considerations regarding the clinical practice of their breeding in captivity. Vet Tecnica 1999; 9: 44-51.

15. Calvete C, Estrada R, Lucientes J, Estrada A, Telletxea I. Correlates of helminth community in the red-legged partridge (Alectoris rufa L.) in Spain. J Parasitol 2003; 89: 445-51. [CrossRef]

16. Calvete $C$, Estrada R, Lucientes J, Estrada A. Ectoparasite ticks and chewing lice of red-legged partridge, Alectoris rufa, in Spain. Med Vet Entomol 2003; 17: 33-7. [CrossRef]

17. Potts GR. The Partridge: Pesticides, Predation and Conservation. London: William Collins Sons \& Co. Ltd 1986.

18. Arthur DR. Ixodes tatei n. sp. from Iraq (Acarina: Ixodidae). Parasitology 1959; 49: 108-10. [CrossRef]

19. Sawada I, Molan AL, Saeed IS. Further studies on avian cestodes in Iraq. Jpn J Parasitol 1990; 39: 36-41.

20. Al-Barwari SE, Saeed I. The parasitic communities of the rock pigeon Columbia livia from Iraq: component and importance. (submitted to Acta Parasitol Turcica 2011).

21. Millan J, Gortazar C, Villafuerte R. First record of Haemoproteus sp. parasitizing red-legged partridge (Alectoris rufa). In: The 5th Scientific Meeting of the European Association of Zoo- and Wildlife Veterinarians (EAZWV), combined with the Annual Meeting of the European Wildlife Disease Association (EWDA) 2002.p.471-6.

22. Perrucci S, Marconcini A, Mani P, Macchioni G. Brachylaemus fuscatus: an intestinal trematode of the red partridge (Alectoris rufa). In: The 35th Convegno della Societa Italiana di Patologia Aviare 1996; October 10-11, Forli, Italy. Selezione Veterinaria (8-9): 833-6.

23. Yakimoff WI, Buewitsch B. Zur gragre der Coccidien wildlebender Bogel in Aserbaidschan (Transkaukasus). Arch Protistenkd 1932; 77: 187-91.

24. Yakimoff WI, Matikschwili IL. Coccidiosis of the grey and stone partridge. Parasitology 1936; 28: 146-7. [CrossRef]

25. Davronov $\mathrm{O}$. On the coccidian fauna of the partridges (Alectoris graeca and Ammoperdix griseogularis) in southern Uzbekistan. Uzbekskii Biologischeskii Zhurnal 1985; 1: 47-9.

26. Duszynski DW, Upton SJ, Couch L. The coccidia of Galliformes (chicken, partridge, peacock, pheasant, quail, turkey). In: Coccidia of the World 2001. Available from: URL http://biology.unm.edu/ biology/coccidia/gallif.html

27. Levine ND. The Protozoa Phylum Apicomplexa. Boca Raton, Florida: Corporate Blvd 2000.

28. Ray HN, Hiregauder S. Coccidia from some birds at the Calcutta Zoo. B Calcutta Sch Trop Med 1959; 7: 111-2.

29. Calnek BW. Diseases of Poultry. 10th ed. lowa: lowa State University Press 1997.

30. Al-Hubity IA. Studies on the Parasites of Gallus gallus domesticus in Mosul District, Iraq. Mosul, College of Education, Mosul University, 1976.

31. Zangana MF. Study on the Parasites of Domestic Pigeon Columba livia domestica in Nineva and Some Areas of Erbil and Dohouk Provinces. Mosul, Mosul University, 1982. 
32. Al-Dabbagh KY, Ali NM, Jiad JH, Waheed IN. Some cestodes from the small intestine of the white cheeked bulbul Pycnonoyus leucogenys. In: Proceedings of the 4th Scientific Conference of the Iraqi Scientific Research Council, Baghdad 1986.p.98-103.

33. Al-Janabi BM, Al-Sadi HI, Hayattee ZG. Some parasites of pigeons from Mosul province. J Coll Vet Med Mosul Iraq 1980; 1: 15-26.

34. Al-Aloosi JAA. A Survey of Alimentary Canal Helminths of Two Birds; Gul (Larus ridibundus) and Wood Pigeon (Columba palumbus) From Baghdad and Baiji Areas. Baghdat, Baghdad University, 985.

35. Khalaf KJ. A collection of insects from Iraq. Iraqi Natural History Museum Baghdad 1959; 17: 1-17.

36. Abul-Hab J. Biting lice of chicken and pigeons in Baghdad area. Bull Biol Res Centre Iraq 1975; 4: 1-36.
37. Abdul-Karim RM, Jassim BA, Naser NS. Infestation and occurrence of ectoparasites (lice, ticks and mites) of pigeons in Erbil area. Bull Entomol New Delhi 1988; 29: 173-7.

38. Al-Muffti SA, Tayeb IT. Survey of poultry tick Argas persicus (Argasidae) in Dohuk governorate. Journal of Dohuk University Iraq 2004; 7: 13-6.

39. Tantawi HH, Al-Moslih MI, Hassan FK, Al-Ani FS. Crimean- Congo Haemorrhagic Fever. Baghdad, Iraq: Al-Muthanna Printing and Publishing House 1980.

40. Al-Tikriti SK, Tantawi HH, Hassan FK, Jurji FJ. Rift Valley Fever. Baghdad, Iraq: Ministry of Education Press 1981.

41. Tompkins DM, Parish DMB, Hudson PJ. Parasite-mediated competition among red-legged partridges and other lowland gamebirds. J Wldl Manage 2002; 66: 445-50.[CrossRef] 